\title{
Evaluation of the transfer of passive immunity by the analysis of immunoglobulin and serum proteins of Holstein calves
}

\section{Avaliação da transferência de imunidade passiva através da análise de imunoglobulinas e proteínas séricas em bezerras da raça holandês}

\author{
Ricardo Augusto Santos Garcia'; Werner Okano ${ }^{2}$; \\ Flavio Antonio Barca Junior²; Luiz César da Silva²; \\ Luiz Fernando Coelho da Cunha Filho'; ; Julio Augusto Naylor Lisboa ${ }^{3}$; \\ Mara Regina Stipp Balarin'; Selwyn Arlington Headley ${ }^{5 *}$
}

\begin{abstract}
This present study evaluated the serum concentrations of the fractional and total proteins, the immunoglobulin concentrations, and the dynamics of passive immune transfer in 25 female Holstein calves. All calves were maintained with their respective dams for 24 hours during which the ingestion of colostrum was done ad libitum. The determinations were done within 24 hours after suckling and at 30 days of age. The gamma fraction of proteins was the predominant immunoglobulin observed $24 \mathrm{hrs}$ after the suckling of colostrum, followed by beta, alpha 2, and alpha1. 30 days later, the beta fraction was more elevated, followed by gamma, and the alpha fractions. The concentrations of serum albumin increased proportionally with age, but the concentrations of total proteins remained unaltered. Most calves $(56 \% ; 14 / 25)$ demonstrated effective passive immune transfer of immunoglobulins; transfer was within acceptable limits for $36 \%(9 / 25)$ but was inadequate in $8 \%(2 / 25)$ of the calves evaluated.
\end{abstract}

Key words: Colostrum, passive immunity, gammaglobulin, cattle

\section{Resumo}

Este presente estudo avaliou as concentrações séricas da proteína total, suas frações, as concentrações de imunoglobulinas e a dinâmica de transferência da imunidade passiva em 25 bezerras da raça Holandês variedade preto e branco. Todas as bezerras permaneceram com suas respectivas mães até 24 horas após o nascimento, durante este período a ingestão de colostro foi realizada ad libitum. As determinações foram feitas após a ingestão do colostro às 24 horas após o nascimento e aos 30 dias de idade. As gamaglobulinas foram predominantes às 24 horas após a ingestão de colostro, seguida pelas frações beta e alfa. Aos 30 dias a fração beta foi a mais elevada, seguida pela gama e as frações alfa. A concentração de albumina sérica aumentou proporcionalmente com a idade, mas a concentração de proteína total manteve-se inalterada. A maior parte das bezerras $(56 \% ; 14 / 25)$ demonstrou transferência passiva imune eficaz de imunoglobulinas; a transferência de imunidade foi dentro dos limites aceitáveis para 36\% (09/25), mas não foi suficiente em $8 \%(02 / 25)$ das bezerras avaliadas.

Palavras-chave: Colostro, imunidade passiva, gamaglobulina, bovino

\footnotetext{
1 Médico Veterinário, COLARI Universidade Norte do Paraná, Mandaguari Arapongas, PR. E-mail: ricardopiraju@hotmail

2 Profs. Universidade Norte do Paraná, UNOPAR, Arapongas, PR. E-mail: vetwerner@gmail.com; flavio.barca@unopar.br; silvaluizcesar@gmail.com; luiz.cunha@unopar.br

3 Prof. da Universidade Estadual de Londrina, UEL, Londrina, PR. E-mail: janlisboa@uel.br

4 Prof $^{a}$ da UEL, Londrina, PR. E-mail: maravet@uel.br

5 Pesquisador, Universidade Norte do Paraná, Arapongas, PR. E-mail: headleysa@gmail.com

Author for corespondence
} 


\section{Introduction}

The synepitheliochorial placentation of cattle does not permit the passage of immunoglobulins during fetal life (BOWEN, 2011), which largely prevents transplacental transfer of immunoglobulin molecules, resulting in neonatal calves being dependent on antibodies received via colostrum (TIZARD, 2009). During pregnancy the fetus is maintained within a sterile environment, but at and after birth, the neonate resides in an unsterile system. Consequently, the ingestion and absorption of adequate amounts of immunoglobulins via colostrum is essential for the health of neonatal calves whose current defence system is based primarily on colostrum acquired antibodies (RADOSTITS et al., 2007).

The passive immunity acquired by the neonate ruminant is dependent on several factors including: period between birth and the ingestion of colostrum, the order of birth, presence of acute mastitis, the volume of colostrum ingested, managerial systems that prevents or impede contact between cow and calf (particularly those of first calving), the quantity of immunoglobulins contained within the colostrum and the rate of immunoglobulin transfer through the intestinal epithelium (GILBERT et al., 1988; VENTORP; MICHANEK, 1992). Additional several studies have suggested the existence of the influence of breed differences on the concentration of immunoglobulins contained within the colostrum (NORMAN; HOHENBOKEN; KELLEY, 1981).

The absorbed immunoglobulins protect the neonate against systemic invasion by microorganisms and septicemias during the neonatal period. In calves, passive immunity also influences the occurrence of respiratory disease during the first few months of life and might be a determinant of productivity throughout adult life (RADOSTITS et al., 2007). Therefore, understanding the dynamics of passive immunity in neonatal calves is of extreme importance in preventing disease. This manuscript investigated the dynamics of passive immunity in neonatal calves by evaluating the concentrations of serum immunoglobulins, globulins, and total serum protein.

\section{Materials and Methods}

This study was done during January to March, 2009 at a dairy farm located within the municipality of Rolândia, Paraná, Southern Brazil; 25 recently born, female, Holstein calves were used during this experiment. The cows and calves were maintained together for $24 \mathrm{hrs}$, during which the calves were allowed to ingest colostrum ad libitum. After this period, the calves were separated from their dams, placed in individual pens, and received an additional four litres of colostrum twice per day (morning and afternoon) during two consecutive days. After this three-day period, each calf received 4 litres of natural milk/day via bucket feeding, with free access to hay, and commercial ration.

Two collections of blood, obtained from the jugular vein, were done: at 24 hours after birth and when the calves were 30 days of age. Blood was collected by the usage of sterile collecting systems without anticoagulant. Serum samples were obtained from each calf, placed into pre-labelled sterile recipients, and stored at $-20{ }^{\circ} \mathrm{C}$ until used.

All serum samples were processed at the Laboratory of Clinical Pathology, Universidade Estadual de Londrina, Paraná, Brazil. The concentration of total proteins was determined by using the biuret method (GORNAL; BARDAWILL; DAVID, 1949) with the aid of commercial reagents (QUIBASA, Química Básica Ltda, Belo Horizonte, MG, Brazil) and spectrophotometric analysis (Bio 2000, BIOPLUS). The concentrations of fractioned proteins (albumin, alpha ${ }_{1}$, alpha ${ }_{2}$, beta, and gammaglobulins) were determined by agarose gel electrophoresis (KREMERS; BRIERE; BATSAKIS, 1967), using a commercially produced gel (CELM, Cia Equipadora de Laboratórios Modernos, Barueri, SP, Brazil) with pH 9.5Tris buffer. Electrophoresis was done at $100 \mathrm{~V}$ for 20 minutes. The gel was 
stained with $2 \%$ amido black dye (CELM), and then unstained by emersion in a $5 \%$ acetic acid solution (Labsynth Produtos para Laboratórios Ltda, Diadema, SP, Brazil). The protein fractions were determined by the software SDS-60 of the SE-250 System (CELM). The albumin: globulin ratio (A/G ratio) was determined by calculation.

The concentration of serum immunoglobulin $\mathrm{G}$ (IgG) was estimated by the zinc sulphate turbidity technique (PFEIFFER; MCGUIRE, 1977). One hour thereafter, the absorbance of the solution was determined by spectrophotometric analysis using a wavelength of $620 \mathrm{~nm}$ (E225-D, CELM); three readings were made and an arithmetic average was determined. The amount of IgG was calculated by using established standardized concentrations (400, 800,1600 , and $3200 \mathrm{mg} / \mathrm{dL}$ ) of bovine IgG by using the Single Radial Immunodiffusion (SRID) Assay kit (VRMD Inc., Pullman, WA, USA). Samples whose estimated values were more than $3200 \mathrm{mg} /$ $\mathrm{dL}$ were reprocessed, after diluting $(1: 1)$ the serum with distilled water.

GGT was determined by the using kinetic method using commercial reagents (Gold Analisa - Gama GT, Belo Horizonte, MG, Brazil); the absorbance measurement was determined by a spectrophotometer (E225-D, CELM), with reading done at a wavelength of $405 \mathrm{~nm}$.

All results were statistically evaluated by the by the paired $T$ test by using the software MINITAB 13.0 (STATE COLLEGE, PA, USA: Minitab Inc. 2000). The experimental procedures used during this study were approved (protocol 008/09) by the Animal Ethics Committee of the Universidade Norte do Paraná, Arapongas, Brazil.

\section{Results and Discussion}

his study has demonstrated that the gamma fraction of proteins was the predominant immunoglobulin observed $24 \mathrm{hrs}$ after the suckling of colostrum, followed by beta, alpha 2, and alpha1 (Fig. 1). However, 30 days later, the beta fraction was more elevated, followed by gamma, and the alpha fractions. These results suggest that beta immunoglobulin is predominant during suckling in accordance with the results of previous studies (BORGES et al.,72001). The concentration of gammaglobulins observed $24 \mathrm{hrs}$ after the ingestion of colostrum was $1.34 \mathrm{~g} / \mathrm{dl}$ (Figure 1); similar results were previously described (TENNANT et al., 1969), while more elevated values $(2.14 \mathrm{~g} / \mathrm{dl})$ were observed in another study (FEITOSA et al., 2001). Nevertheless, the elevated concentrations of gammaglobulins demonstrated during the first 24 hours of life, suggest that the suckling of colostrum was responsible for the transfer of maternal antibodies (LUCCI, 1989; TIZARD, 2009).

The concentration of total proteins remained almost statistically unaltered during the period evaluated $(\mathrm{p}=0,221)$; with a slight reduction orom $5.64 \mathrm{~g} / \mathrm{dl}$ at $24 \mathrm{hrs}$ after suckling to $5.33 \mathrm{~g} / \mathrm{dl}$ at the end of the experiment. However, comparatively elevated values $(6.55 \mathrm{~g} / \mathrm{dl})$ were observed in a similar study (FEITOSA et al., 2001). The stabilization of the values of total protein observed during this study might be predominantly related to the characterization of a transitional phase that begins with the catabolism of passively acquired antibodies to an anabolic phase of endogenous production of antibodies.

There was an increase in the serum concentration of albumin $(\mathrm{p}=0,038)$ during this study from 2.88 $\mathrm{g} / \mathrm{dl}$ at $24 \mathrm{hrs}$ to $3.18 \mathrm{~g} / \mathrm{dl} 30$ days. The increase in serum concentration of albumin relative to age was previously described (FAGLIARI et al., 1998; FEITOSA et al., 2001; LEAL et al., 2003), while age seemed to have no influence on the serum albumin concentration in another study (DANIELE et al., 1994). 
Figure 1. Serum concentrations of fractioned proteins of Holstein calves determined at $24 \mathrm{hrs}$ after suckling and at 30 days of age ( $\alpha$, alpha; $\beta$, beta; $\gamma$, gamma; TG, total globulins).

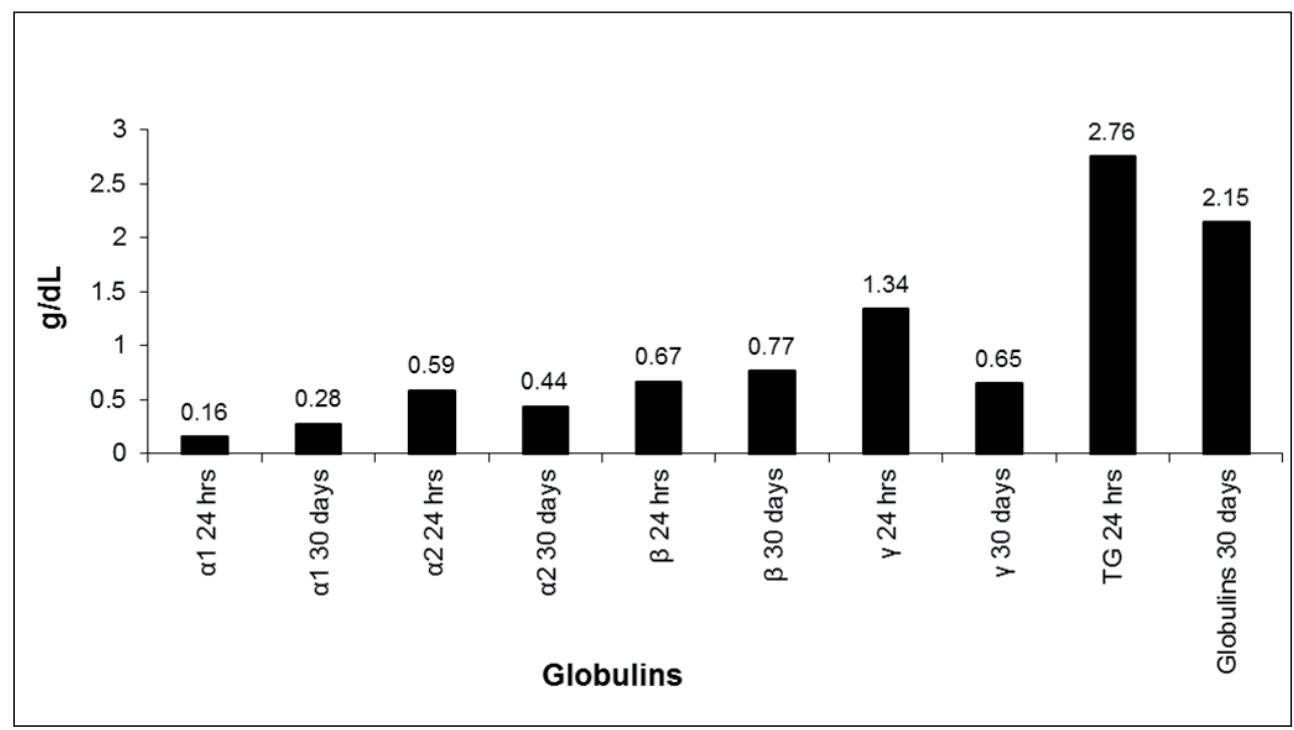

Source: Elaboration of the authors.

The albumin/globulin ratio (A/G ratio) was 1.26 $\mathrm{g} / \mathrm{dl}$ at $24 \mathrm{hrs}$ and $1.58 \mathrm{~g} / \mathrm{dl} 30$ days later; similar results were described (FEITOSA et al., 2001). However, the globulin component of this ratio was comparatively more elevated during the first determination $(\mathrm{A} / \mathrm{G}$ ratio; $2.88 / 2.76)$ with reduced values $(\mathrm{A} / \mathrm{G}$ ratio; 3.18/2.15) at the second; this initial elevation of globulin might be directly related to the peak of the gamma fraction of the protein content due to ingestion of colostrum and consequent hepatic synthesis, with reduced values being associated with protein degradation.

The critical levels of serum IgG of calves considered as indicators of successful passive immune transfer in cattle varies from $1000 \mathrm{mg} /$ dL to $1600 \mathrm{mg} / \mathrm{dL}$ (MCGUIRE; ADAMS, 1982; RADOSTITS et al., 2007). Values between 500 and $1500 \mathrm{mg} / \mathrm{dL}$ (SELIM et al., 1995), or 600 and 1600 mg/dL (MCGUIRE; ADAMS, 1982) are indicative of partial transfer. Using the values established by Selim et al. (1995), most calves $(56 \% ; 14 / 25)$ had adequate passive transfer of immunoglobulins; transfer was restricted in 36\% (9/25) calves; and only $8 \%(2 / 25)$ were below this threshold. The differences observed during this study might be related to the spontaneous feeding of colostrum, since it was not possible to effectively determine if suckling occurred and the amount of colostrum ingested.

There was marked average reduction in the serum activity of gamma-glutamyltransferase (GGT). GGT is present in large concentrations in bovine colostrum and large amounts are absorbed by the intestinal cells of new born calves (BRAUN et al., 1982; FAGLIARI et al, 1996; ZANKER; HAMMON; BLUM, 2001). Consequently, the serum GGT activity is an indirect indicator of the ability of neonates to efficiently absorb immunoglobulins (FEITOSA et al., 2001). Therefore, it can be inferred that the severe reduction in the concentration of GGT observed in this study would suggest that various proteins other than immunoglobulins were absorbed and that GGT activity changed in part differently during the first $30 \mathrm{~d}$ of life than immunoglobulins. 


\section{Acknowledgements}

The authors are grateful to Dr. Jean Adriano Baudra, and Dr. Evandro Doine Vettorat, for their assistance during the field collection and laboratory preparation of samples used during this study. The authors are also thankful for financial assistance received from the Pro-Reitoria de Pesquisa UNOPAR and FUNADESP.

\section{Bioethics and Biossecurity Committee Approval}

The experimental procedures used during this study were approved (protocol 008/09) by the Animal Ethics Committee of the Universidade Norte do Paraná, Arapongas, Brazil.

\section{References}

BORGES, A. S.; FEITOSA, F. L. F.; BENESI, F. J.; BIRGEL, E. H.; MENDES, L. C. N. Influência da forma de administração e da quantidade fornecida de colostro sobre a concentração de proteína total e de suas frações eletroforéticas no soro sangüíneo de bezerros da raça Holandesa. Arq. Bras. Med. Vet. Zootec., 2001, v. 53, n. 5, p. 629-634.

BOWEN, R. A. Pathophysiology of the reproductive system. Colorado State Univ, USA. 2011. Available at: $\quad<$ http://www.vivo.colostate.edu/hbooks/pathphys/ reprod/index.html>. Accessed at: 29 abr. 2011.

BRAUN, J. P.; TAINTURIER, D.; LAUGIER, C.; BÉRNARD, P.; THOUVENOT, J. P.; RICO, A. G. Early variations of blood plasma gamma-glutamyl transferase in new-born calves: A test of colostrum intake. J. Dairy Sci., v. 65, p. 2178-2181, 1982. Available at: $\quad<$ http://download.journals.elsevierhealth.com/pdfs/ journals/0022-0302/PIIS002203028282479X.pdf>. Accessed at: 20 abr. 2011.

DANIELE, C.; MACHADO NETO, R.; BARACAT, R. S.; BESSI, R.; PACKER, I. U. Efeito de diferentes manejos de fornecimento prolongado de colostros sobre os níveis de proteína e albumina sérica e desempenho de bezerras recém-nascidas. Sci. Agric., v. 51, n. 2, p. 381388, 1994. Available at: <http://www.scielo.br/pdf/sa/ v51n2/27.pdf $>$. Accessed at: 20 abr. 2011.
FAGLIARI, J. J.; SANTANA, A. E.; LUCAS, F. A.; CAMPOS FILHO, E.; CURI, P. R. Constituintes sanguíneos de bovinos recém-nascidos das raças Nelore (Bos indicus) e Holandesa (Bos taurus) e de bubalinos (Bubalus bubalis) da raça Murrah. Arq. Bras. Med. Vet. Zootec., Belo Horizonte, v. 50, n. 3, p. 253-262, 1998.

FAGLiARI, J. J.; OLIVEIRA, E. C.; PEGORER, M. F.; FERRANTE JÚNIOR, L. C.; CAMPOS FILHO, E. Relação entre o nível sérico de gamaglobulinas e as atividades de gamaglutamiltransferase, fosfatase alcalina e aspartato aminotransferase de bezerros recém-nascidos. Arq. Bras. Med. Vet. Zootec., Belo Horizonte, v. 48, n. 2, p. 105-112, 1996.

FEITOSA, F. L. F.; BIRGEL, E. H.; MIRANDOLA, R. M. S.; PERRI, S. H. V. Diagnóstico de falha de transferência de imunidade passiva em bezerros através da determinação de proteína total e de suas frações eletroforéticas, imunoglobulinas $\mathrm{G}$ e Me da atividade da gama glutamil transferase no soro sangüíneo. Ciência Rural, Santa Maria, v. 31, n. 2, p. 251-255, 2001. Available at: <http://www.scielo.br/pdf/cr/v31 n2/a10v31n2.pdf>. Accessed at: 18 abr. 2011.

GILBERT, R. P.; GASKINS, C. T.; HILLERS, J. K.; PARKER, C. F.; McGUIRE, T. C. Genetic and enviromental factors affeting immunoglobulin G1 concentrations in ewe colostrum and lamb serum. $J$. Anim. Sci., v. 66, n. 4, p. 855-863, 1988. Available at: $<$ http://jas.fass.org/content/66/4/855.full.pdf $>$. Access at: 18 abr. 2011.

GORNAL, A. G.; BARDAWILL, C. J.; DAVID, M. M. Determination of serum proteins by means of biuret reaction. J. Biol. Chem., Baltimorl, v. 177, n. 2, p. 751$766,1949$.

KREMERS, B.; BRIERE, R. O.; BATSAKIS, J. G. Reflectance densitometry of cellulose acetate protein electrophoresis. Am. J. Med. Technol., Park Ridgl, v. 33, p. 28-34, 1967.

LEAL, M. L. R.; BENESI, F. J.; LISBÔA, J. A. N.; COELHO, C. S.; MIRANDOLA, R. M. S. Proteinograma sérico de bezerras sadias, da raça holandesa, no primeiro mês pós-nascimento. Braz. J. Vet. Res. Anim. Sci., v. 40, n. 2, p. 138-145, 2003. Available at: <http://www.scielo. br/pdf/bjvras/v40n2/v40n2a08.pdf $>$. Accessed at: $22 \mathrm{abr}$. 2011.

LUCCI, C. S. Bovinos leiteiros jovens: nutrição manejo, doenças. São Paulo: Nobel, 1989. 371 p.

McGUIRE, T. C.; ADAMS, D. S. Failure of colostral immunoglobulin transfer to calves: prevalence and diagnosis. Compend. Contin. Educ. Vet., Yardlel, v. 4, n. 1, p. S35-S40, 1982. 
NORMAN, L. M.; HOHENBOKEN, W. D.; KELLEY, $\mathrm{K}$. W. Genetic differences in concentration of immunoglobulins g 1 and $\mathrm{m}$ in serum and colostrum of cows and in serum of neonatal calves. J. Anim. Sci., v. 53, n. 6 , p. $1465-1472,1981$. Available at: <http://jas.fass. org/content/53/6/1465.full.pdf $>$. Access at: 15 abr. 2011.

PFEIFFER, N. E.; McGUIRE, T. C. A sodium sulfite-precipitation test for assesment of colostral immunoglobulin transfer to calves. J. Am. Vet. Med. Assoc., Schaumburl, v. 170, n. 8, p. 809-811, 1977.

RADOSTITS, O.; GAY, C. C.; HINCHCLIFF, K. W.; CONSTABLE, P. D. Veterinary medicine: a textbook of the diseases of cattle, horses, sheep, pigs, and goats. Philadelphia: Saunders/Elsevier, 2007. 2156 p.

SELIM, S. A.; SMITH, B. P.; CULlOR, J. S.; BLANCHARD, P. Serum immunoglobulins in calves: their effects and two easy, reliable means of measurement. Vet. Med., Ames, Il, v. 90, n. 4, p. 387-404, 1995.
TENNANT, B.; HARROLD, D.; REINA-GUERRA, M.; LABEN, R. C. Neonatal alterations in serum gamma globulin levels of Jersey and Holstein-Friesian calves. Am. J. Vet. Res., Chicagl, v. 30, n. 2, p. 345-354, 1969.

TIZARD, I. R. Veterinary immunology: an introduction. St. Louis: Saunders/Elsevier, 2009. 574 p.

VENTORP, M.; MICHANEK, P. The importance of udder and teat conformation for teat seeking by the newborn calf. J. Dairy Sci., v. 75, n. 1, p. 262-268, 1992. Available at: $<$ http://download.journals. elsevierhealth. com/pdfs/journals/0022-0302/PIIS 0022030292777613. pdf $>$. Accessed at: 22 abr. 2011.

ZANKER, I. A.; HAMMON, H. M.; BLUM, J. W. Activities of glutamyltransferase, alkaline phosphatase and aspartate-aminotransferase in colostrum, milk and blood plasma of calves fed first colostrums at 0-2, 6-7, 12-13 and 24-25 h after birth. J. Vet. Med. A, Physiol. Pathol. Clin. Med., Berlil, v. 48, n. 3, p. 179-185, 2001. 